\title{
Phase Diagrams of Ternary $\pi$-Conjugated Polymer Solutions for Organic Photovoltaics
}

\author{
Jung Yong Kim (10
}

check for

updates

Citation: Kim, J.Y. Phase Diagrams of Ternary $\pi$-Conjugated Polymer Solutions for Organic Photovoltaics. Polymers 2021, 13, 983. https:// doi.org/10.3390/polym13060983

Academic Editor: Hiromasa Goto

Received: 3 March 2021

Accepted: 20 March 2021

Published: 23 March 2021

Publisher's Note: MDPI stays neutral with regard to jurisdictional claims in published maps and institutional affiliations.

Copyright: (C) 2021 by the author. Licensee MDPI, Basel, Switzerland. This article is an open access article distributed under the terms and conditions of the Creative Commons Attribution (CC BY) license (https:/ / creativecommons.org/licenses/by/ $4.0 /)$.
School of Chemical Engineering and Materials Science and Engineering, Jimma Institute of Technology, Jimma University, Post Office Box 378 Jimma, Ethiopia; jungyong.kim@ju.edu.et

\begin{abstract}
Phase diagrams of ternary conjugated polymer solutions were constructed based on Flory-Huggins lattice theory with a constant interaction parameter. For this purpose, the poly(3hexylthiophene-2,5-diyl) (P3HT) solution as a model system was investigated as a function of temperature, molecular weight (or chain length), solvent species, processing additives, and electronaccepting small molecules. Then, other high-performance conjugated polymers such as PTB7 and PffBT4T-2OD were also studied in the same vein of demixing processes. Herein, the liquid-liquid phase transition is processed through the nucleation and growth of the metastable phase or the spontaneous spinodal decomposition of the unstable phase. Resultantly, the versatile binodal, spinodal, tie line, and critical point were calculated depending on the Flory-Huggins interaction parameter as well as the relative molar volume of each component. These findings may pave the way to rationally understand the phase behavior of solvent-polymer-fullerene (or nonfullerene) systems at the interface of organic photovoltaics and molecular thermodynamics.
\end{abstract}

Keywords: conjugated polymer; phase diagram; ternary; polymer solutions; polymer blends; FloryHuggins theory; polymer solar cells; organic photovoltaics; organic electronics

\section{Introduction}

Since Flory-Huggins lattice theory was conceived in 1942, it has been widely used because of its capability of capturing the phase behavior of polymer solutions and blends [1-3]. Specifically, in 1949, Scott and Tompa applied the Flory-Huggins model to ternary systems, such as solvent-polymer-polymer and nonsolvent-solvent-polymer [4-6]. Since then, Loeb and Sourirajan invented the integrally skinned asymmetric membrane in 1963 [7], so the Flory-Huggins theory has been more utilized to describe the film-formation process and morphology through nonsolvent induced phase inversion (NIPI) or immersion precipitation from the ternary nonsolvent-solvent-polymer system [8,9]. Meanwhile, the original Flory-Huggins theory has been further extended by considering polymer-size (or polydispersity) and polymer-composition dependent interaction parameters [10-14]. However, although this generalization of the Flory-Huggins theory contributed to the enhancement of accuracy in describing experimental data, the theory should be maintained in its simplicity, allowing the original model to still function in the scientific society [15-19].

Importantly, in 1976, the new $\pi$-bonded macromolecules showing the full range from insulator to metal through doping were discovered by Heeger, MacDiarmid and Shirakawa [20-22]. Then in 1992, the photoinduced electron transfer between a conjugated polymer and fullerene was demonstrated on a picosecond time scale [23], paving the way for the development of bulk-heterojunction (BHJ) polymer/fullerene solar cells [24,25]. Here, for the desired BHJ structural morphologies, the phase scale of the active layer should be controlled within exciton diffusion length $\sim 10 \mathrm{~nm}$ in organic semiconductors $[26,27]$ (or 20-47 $\mathrm{nm}$ for nonfullerene acceptors (NFAs) [28]; 70 nm for ordered conjugated polymers [29]; >200 nm for conjugated block-copolymer nanofibers) [30], motivating to understand the phase-separation mechanism through the calculation of ternary phase 
diagrams containing the binodal, spinodal, tie line, and critical point [31-33]. Then, the binodal curves were calculated for the ternary polyfluorene derivative-fullerene-solvent systems [34]. In the following year 2008, more progress was made in polymer thermodynamics, that is, the construction of the phase diagrams for the binary poly(3-hexylthiophene-2,5diyl) (P3HT)/[6,6]-phenyl $\mathrm{C}_{61}$-butyric acid methyl ester $\left(\mathrm{PC}_{61} \mathrm{BM}\right)$ system based on thermal and optical analyses $[35,36]$. Subsequently, other binary and ternary phase diagrams have been further constructed for organic photovoltaics (OPV) [37-53]. Importantly, the theoretical description for the ternary solvent-polymer-fullerene and solvent-polymer-NFA systems helps to rationally understand the morphology-generation mechanism for the active layer of solar cells, although it is not as sophisticated, compared to the phase inversion membrane field [46-53].

To understand the bicontinuous morphologies in the demixed donor/acceptor blends for OPV, both thermodynamics and kinetics are usually required, concerning both the equilibrium and dynamics of liquid-liquid (L-L) and liquid-solid (L-S) phase transition $[30-32,45,54,55]$. Furthermore, L-L demixing could be subdivided into spinodal decomposition (SD) and nucleation and growth (NG), whereas the L-S demixing could be crystallization, gelation, and vitrification depending on the properties of materials $[55,56]$. To date, regarding the L-L and L-S demixing of ternary conjugated polymer solutions, there have been two kinds of viewpoints in literature [48,57-59]. One is the 1-2 nm thick surfacedirected SD followed by crystallization in the $\mathrm{P} 3 \mathrm{HT} / \mathrm{PC}_{61} \mathrm{BM}$ system [57], and the other is its reverse process, i.e., the initial crystallization (self-assembly) of $\mathrm{P} 3 \mathrm{HT}$ followed by the lateral/vertical diffusion of $\mathrm{PC}_{61} \mathrm{BM}$ molecules leading to the $\mathrm{NG}$ process [59]. However, it is expected that the sequence of the above L-L to L-S (or its reverse) phase transition might be dependent on the time allowed for crystallization [60] through energy minimization and packing from the ternary polymer solution during a non-equilibrium spin-casting process.

In previous studies $[18,19]$, the phase behavior of a binary $\mathrm{P} 3 \mathrm{HT} / \mathrm{PC}_{61} \mathrm{BM}$ blend was elucidated, leading to temperature-composition phase diagrams [18]. Then the binary low bandgap conjugated polymer solutions and blends were investigated, resulting in various phase diagrams as a function of solvent species, polymer, and chain length [19]. In this study, our interests were further extended to ternary polymer solutions such as solvent-polymer-fullerene and solvent-polymer-NFA systems, in which the composition effect on the phase behavior was examined through ternary phase diagrams. Note that, for this work, two assumptions were made as follows: (1) A homogenous ternary solution is prepared in the first stage. (2) Then through the quenching process, the L-L demixing will precede any crystallization. Then, based on these assumptions, a semicrystalline polymer can be treated as an amorphous chain molecule [61], which could be phase-separated through the L-L phase transition $[3,16]$. For example, the ternary P3HT solutions were studied as a function of temperature, molecular weight, solvent species $[\mathrm{CB}$, chloroform $(\mathrm{CF})$, toluene $(\mathrm{TOL})]$, processing additive (DIO, and ODT), and electron acceptor $\left(\mathrm{PC}_{61} \mathrm{BM}, \mathrm{PC}_{71} \mathrm{BM}\right.$, and ITIC). Here, DIO and ODT stand for 1,8diiodooctane and 1,8-octanedithiol, respectively, whereas ITIC denotes 3,9-bis(2-methylene(3-(1,1-dicyanomethylene)-indanone))-5,5,11,11-tetrakis(4-hexyl phenyl)-dithieno[2,3-d: $2^{\prime}, 3^{\prime}$ - $\left.\mathrm{d}^{\prime}\right]$-s-indaceno[1,2-b:5,6b'] dithiophene [62]. Then, our analysis was extended to other high-performance low bandgap polymers such as PTB7 and PffBT4T-2OD. Here, PTB7 denotes poly[[4,8-bis[(2-ethylhexyl)oxy]benzo[1,2-b:4,5-b']dithiophene-2,6-diyl] [3fluoro-2-[(2-ethylhexyl)carbonyl]thieno[3,4-b]thiophenediyl]] [63-65], and PffBT4T-2OD stands for poly[(5,6-difluoro-2,1,3-benzothiadiazol-4,7-diyl)-alt-(3,3'"'-di (2-octyldodecyl) $2,2^{\prime} ; 5^{\prime}, 2^{\prime \prime} ; 5^{\prime \prime}, 2^{\prime \prime \prime}$-quarterthiophen-5, $5^{\prime \prime \prime}$-diyl)] [44,66]. Finally, the phase diagrams of ternary $\mathrm{CB} / \mathrm{PTB}$ /ITIC and CB/PffBT4T-2OD/ITIC systems were constructed. Note that, in this work, all the binodal, spinodal, tie line, and critical point data were calculated based on the Flory-Huggins theory with a constant interaction parameter and the molar volume ratio of each component. 


\section{Experimental Methods}

Regioregular P3HT [ $M_{n}=22.0 \mathrm{~kg} / \mathrm{mol}, M_{w}=46.2 \mathrm{~kg} / \mathrm{mol}$, polydispersity index $(\mathrm{PDI})=2.1$, and molecular formula $\left.=\left(\mathrm{C}_{10} \mathrm{H}_{14} \mathrm{~S}\right)_{n}\right]$ was purchased from Rieke Metals $\mathrm{PC}_{61} \mathrm{BM}$ and $\mathrm{PC}_{71} \mathrm{BM}$ were provided from Nano-C. The molecular weight of $\mathrm{P} 3 \mathrm{HT}$ was measured by a gel permeation chromatograph (GPC) (PL-GPC50) equipped with a refractive index detector using THF as an eluent. The columns were calibrated using a standard polystyrene sample. Contact angles of water were measured for the P3HT:PC 61 BM $(=1: 0.8$ and 1:1 weight ratio) blend films on a glass slide using a contact angle analyzer (Phoenix $300+/$ LCA10) as explained in previous studies $[18,19]$.

\section{Theoretical Methods}

The Flory-Huggins lattice model $[1-3,14,67]$ was employed to construct the ternary phase diagrams. Here, the Gibbs free energy of mixing $\left(\Delta G_{m i x}\right)$ for a ternary system is given as follows [3-6,10,11,15]:

$$
\frac{\Delta G_{m i x}}{R T}=n_{1} \ln \phi_{1}+n_{2} \ln \phi_{2}+n_{3} \ln \phi_{3}+\chi_{12} n_{1} \phi_{2}+\chi_{13} n_{1} \phi_{3}+\chi_{23} n_{2} \phi_{3}
$$

where $R$ is the Gas constant, $T$ is temperature $(\mathrm{K}), n_{i}$ is the number of moles of component $i, \phi_{i}$ is the volume fraction of component $i$, and $\chi_{i j}$ is Flory-Huggins interaction parameter between components $i$ and $j$. In Equation (1), it is notable that $\chi_{\text {ternary }}=\chi_{123}$ (a ternary interaction parameter) is assumed to be zero. Furthermore, in this study, the $\chi_{i j}$ parameter is defined as follows [46-53,67]:

$$
\chi_{i j}=\frac{v_{1}}{R T}\left(\delta_{i}-\delta_{j}\right)^{2}+0.34
$$

where $v_{1}$ is molar volume of component 1 (usually, solvent), and $\delta_{i \text { or } j}\left(=\sqrt{\delta_{d}^{2}+\delta_{p}^{2}+\delta_{h}^{2}}\right.$ where $\delta_{d}, \delta_{p}$, and $\delta_{h}$ are the physical quantities from dispersion force, polar force, and hydrogen bonding, respectively) is the solubility parameter of component $i$ or $j$, estimated from the relationship of $\delta_{i} \propto \sqrt{\gamma_{s v}}[18,19,34,46]$. Here, the surface energy $\left(\gamma_{s v}\right)$ for solidvapor could be numerically calculated from the contact angle $(\theta)$ data according to $\mathrm{Li}$ and Neumann [68,69]:

$$
\cos \theta=-1+2 \sqrt{\frac{\gamma_{s v}}{\gamma_{l v}}} e^{-\beta\left(\gamma_{l v}-\gamma_{s v}\right)^{2}}
$$

where $\beta=0.0001115\left(\mathrm{~m}^{2} / \mathrm{mJ}\right)^{2}$, and $\gamma_{l v}$ is surface energy for liquid-vapor. Importantly, in many polymer systems, $\chi_{i j}$ was reported to be a composition-dependent parameter $[10-12,14]$. However, in this study $\chi_{i j}$ is assumed to be a constant because, to date, there has been no available data for this composition dependence in conjugated polymer science.

The chemical potential $\left(\Delta \mu_{i}\right)$ of component $i$, i.e., the first derivative of the free energy, could be calculated using the equations below $[3-6,10,11,15]$ :

$$
\begin{gathered}
\frac{\Delta \mu_{1}}{R T}=\ln \phi_{1}+\left(1-\phi_{1}\right)-s \phi_{2}-r \phi_{3}+\left(\chi_{12} \phi_{2}+\chi_{13} \phi_{3}\right)\left(\phi_{2}+\phi_{3}\right)-\chi_{23} s \phi_{2} \phi_{3} \\
\frac{\Delta \mu_{2}}{R T}=\ln \phi_{2}+1-\left(\frac{1}{s} \phi_{1}+\phi_{2}+\frac{r}{s} \phi_{3}\right)+\left(\chi_{12} \frac{1}{s} \phi_{1}+\chi_{23} \phi_{3}\right)\left(\phi_{1}+\phi_{3}\right)-\chi_{13} \frac{1}{s} \phi_{1} \phi_{3} \\
\frac{\Delta \mu_{3}}{R T}=\ln \phi_{3}+1-\left(\frac{1}{r} \phi_{1}+\frac{s}{r} \phi_{2}+\phi_{3}\right)+\left(\chi_{13} \frac{1}{r} \phi_{1}+\chi_{23} \frac{s}{r} \phi_{2}\right)\left(\phi_{1}+\phi_{2}\right)-\chi_{12} \frac{1}{r} \phi_{1} \phi_{2}
\end{gathered}
$$

where $s=v_{1} / v_{2}, r=v_{1} / v_{3}$, and $s / r=v_{3} / v_{2}$. Here, $v_{2}$ and $v_{3}$ are the molar volumes of components 2 and 3 , respectively. The binodal curve, also called the miscibility gap, could be calculated based on the below equilibrium condition [1-3,14]:

$$
\Delta \mu_{1}^{\alpha}=\Delta \mu_{1}^{\beta} \quad(i=1,2,3)
$$


where $\alpha$ and $\beta$ indicate two different phases, i.e., a polymer lean phase and a polymer rich phase. In the case of the spinodal curve, i.e., the second derivative of the free energy, it could be calculated from the equation below $[3-6,10,11]$,

$$
|G|=\left|\begin{array}{ll}
G_{22} & G_{23} \\
G_{32} & G_{33}
\end{array}\right|=0
$$

where $G_{i j}=\left(\partial^{2} \Delta \bar{G}_{m i x} / \partial \phi_{i} \partial \phi_{j}\right) v_{r e f}$. Here $\Delta \bar{G}_{m i x}$ is Gibbs free energy of mixing with unit volume basis and $v_{\text {ref }}$ is the molar volume of the reference component $\left(=v_{1}\right)$. Then, $G_{23} G_{33}=\left(G_{23}\right)^{2}$. Finally, the critical point for a ternary system (when $\chi_{i j}$ is a constant parameter) could be calculated based on the equation below $[3-6,10,11]$ :

$$
1-s\left(\frac{\phi_{1}^{c}}{\phi_{2}^{c}}\right)^{2}-2 \frac{G_{22}}{G_{23}}\left(1-\frac{G_{22}}{G_{23}}\right)-1-r\left(\frac{\phi_{1}^{c}}{\phi_{3}^{c}}\right)^{2}\left(\frac{G_{22}}{G_{23}}\right)^{3}=0
$$

where $\phi_{1}^{c}, \phi_{2}^{c}$, and $\phi_{3}^{c}$ are the volume fractions of component 1,2 , and 3 at critical point, respectively. However, if $\chi_{i j}$ were a function of composition [10-12], the aforementioned formula should be additionally modified, e.g., Equation (9) should be expanded to $G_{222} G_{33}^{2}-3 G_{223} G_{23} G_{33}+G_{233} G_{23}^{2}-G_{22} G_{23} G_{333}=0$ with $G_{222}=\partial G_{22} / \partial \phi_{2}, G_{223}=\partial G_{22} /$ $\partial \phi_{3}, G_{233}=\partial G_{23} / \partial \phi_{3}$, and $G_{333}=\partial G_{33} / \partial \phi_{3}[5,6,10,11]$. Finally, the results from the aforementioned equations allow the calculation of the ternary phase diagrams containing the binodal, spinodal, tie line, and critical point if the five parameters $\left(\chi_{12}, \chi_{13}, \chi_{23}, s\right.$, and $r$ ) were specified as mentioned elsewhere $[10,11,15]$. Note that in order to avoid trivial solutions, initial guesses for the phase composition should be close to the correct values [11], indicating a trial-and-error method is required for constructing phase diagrams.

\section{Results and Discussion}

Figure 1 shows the chemical structures of (a) electron-donating conjugated polymers (P3HT, PTB7, and PffBT4T-2OD), (b) electron-accepting small molecules ( $\mathrm{PC}_{61} \mathrm{BM}, \mathrm{PC}_{71} \mathrm{BM}$, and ITIC), (c) solvents (CB, CF, and TOL), and (d) processing additives (DIO and ODT). Tables 1 and 2 display the characteristic properties of polymers, electron acceptors, solvents, and additives, from which the five parameters $\left(\chi_{12}, \chi_{13}, \chi_{23}, s\right.$ and $\left.r\right)$ were estimated (see Table 3). Note that in this study, the polymer was assumed to be monodisperse, indicating that PDI was not taken into account.

Table 1. Solubility parameter $\left(\delta_{i}\right)$, molecular weight (MW), molar volume $\left(v_{i}\right)$, density $(\rho)$, chemical structure and reference

\begin{tabular}{|c|c|c|c|c|c|c|c|}
\hline Materials & $\begin{array}{c}\delta_{i}^{*} \\
\left(\mathrm{cal} / \mathrm{cm}^{3}\right)^{1 / 2}\end{array}$ & $\begin{array}{c}\delta_{i} \\
\mathrm{MPa}^{1 / 2}\end{array}$ & $\begin{array}{c}\text { MW } \\
\text { (g/mol) }\end{array}$ & $\begin{array}{c}v_{i} \\
\left(\mathrm{~cm}^{3} / \mathrm{mol}\right)\end{array}$ & $\begin{array}{c}\rho \\
\left(\mathrm{g} / \mathrm{cm}^{3}\right)\end{array}$ & $\begin{array}{l}\text { Chemical } \\
\text { Structure }\end{array}$ & Ref \\
\hline P3HT & 8.7 & 17.83 & 22,000 & 20,000 & 1.1 & $\left(\mathrm{C}_{10} \mathrm{H}_{14} \mathrm{~S}\right)_{\mathrm{n}}$ & {$[18,19]$} \\
\hline PTB7 & 8.8 & 18.03 & 80,000 & 68,376 & 1.17 & $\left(\mathrm{C}_{41} \mathrm{H}_{53} \mathrm{FO}_{4} \mathrm{~S}_{4}\right)_{\mathrm{n}}$ & [65] \\
\hline PffBT4T-2OD & 9.4 & 19.26 & 50,000 & 41,322 & 1.21 & $\left(\mathrm{C}_{62} \mathrm{H}_{88} \mathrm{~F}_{2} \mathrm{~N}_{2} \mathrm{~S}_{5}\right)_{\mathrm{n}}$ & {$[44,70]$} \\
\hline $\mathrm{PC}_{61} \mathrm{BM}$ & 11.3 & 23.15 & 910 & 607 & 1.5 & $\mathrm{C}_{72} \mathrm{H}_{14} \mathrm{O}_{2}$ & {$[18,19]$} \\
\hline $\mathrm{PC}_{71} \mathrm{BM}$ & 11.2 & 22.95 & 1031 & 687 & 1.5 & $\mathrm{C}_{82} \mathrm{H}_{14} \mathrm{O}_{2}$ & {$[18,19]$} \\
\hline ITIC & 11.8 & 24.18 & 1428 & 1152 & 1.24 & $\mathrm{C}_{94} \mathrm{H}_{82} \mathrm{~N}_{4} \mathrm{O}_{2} \mathrm{~S}_{4}$ & [53] \\
\hline
\end{tabular}
for materials. Here, MW is $M_{n}$ in the case of polymers.

* Note that, for calculating the $\chi_{i j}$ parameter in Equation (2), the CGS unit is used instead of the SI unit.

Here, $\chi_{i j}$ was estimated from the solubility parameter $(\delta)$, obtained from contact angle $(\theta)$ measurements and literature sources $[18,19,44,53,65,70-74]$. However, if $\theta$ is measured for the polymer/fullerene blends, it will not provide any decoupled surface energy $\left(\gamma_{s v}\right)$ for each component. Hence, the composition-dependent interaction parameter is not available through the methodology of contact angle measurement. However, for characterization purposes, the contact angles for the blend samples, $\mathrm{P} 3 \mathrm{HT}: \mathrm{PC}_{61} \mathrm{BM}=1: 0.8$ and 1:1, were measured. As shown in Figure 2, the data was not linearly proportional to the blend ratio, indicating that other factors (e.g., $\mathrm{PC}_{61} \mathrm{BM}$ miscibility/solubility limit) [35] might also be 
involved in the determination of surface properties. Therefore, in this work, only the contact angle data from the pure materials were considered when estimating the $\chi_{i j}$ parameters.

(a)
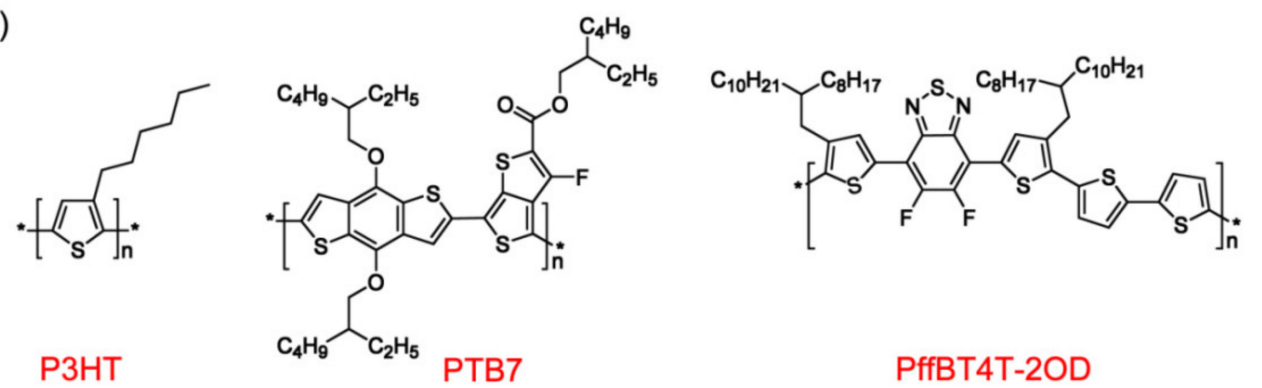

P3HT

PTB7

PffBT4T-2OD

(b)

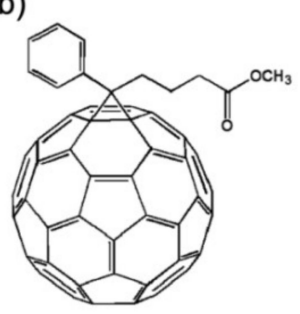

$\mathrm{PC}_{61} \mathrm{BM}$

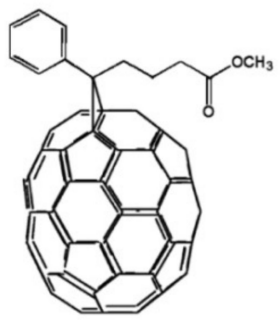

$\mathrm{PC}_{71 \mathrm{BM}}$

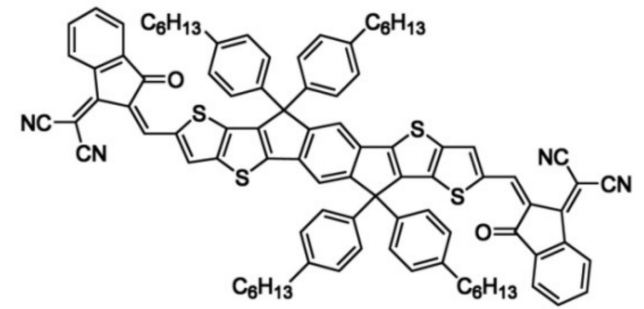

ITIC (c)<smiles>c1ccc2ccccc2c1</smiles>

$\mathrm{CB}$

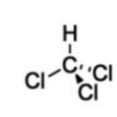

$\mathrm{CF}$

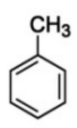

TOL (d)

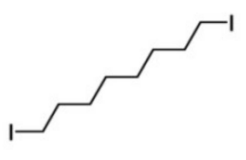

$\mathrm{DIO}$

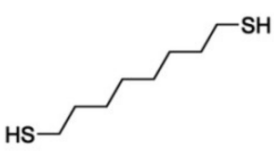

ODT

Figure 1. Chemical structures of (a) electron-donating conjugated polymers, (b) electron-accepting small molecules, (c) solvents, and (d) processing additives.

Table 2. Solubility parameter $\left(\delta_{i}\right)$, molecular weight (MW), molar volume $\left(v_{i}\right)$, density $(\rho)$, boiling point (bp), chemical structure, and reference for solvents and processing additives.

\begin{tabular}{|c|c|c|c|c|c|c|c|c|}
\hline Solvent & $\begin{array}{c}\delta_{i}^{*} \\
\left(\mathrm{cal} / \mathrm{cm}^{3}\right)^{1 / 2}\end{array}$ & $\begin{array}{c}\delta_{i} \\
\mathrm{MPa}^{1 / 2}\end{array}$ & $\begin{array}{c}\mathrm{MW} \\
\left(\mathrm{g} / \mathrm{cm}^{3}\right)\end{array}$ & $\begin{array}{c}v_{i} \\
\left(\mathrm{~cm}^{3} / \mathrm{mol}\right)\end{array}$ & $\begin{array}{c}\rho \\
\left(\mathrm{g} / \mathrm{cm}^{3}\right)\end{array}$ & $\begin{array}{l}\text { bp } \\
\left({ }^{\circ} \mathrm{C}\right)\end{array}$ & $\begin{array}{l}\text { Chemical } \\
\text { Structure }\end{array}$ & Ref \\
\hline CB & 9.5 & 19.47 & 112.56 & 101.41 & 1.11 & 132 & $\mathrm{C}_{6} \mathrm{H}_{5} \mathrm{Cl}$ & [71] \\
\hline $\mathrm{CF}$ & 9.2 & 18.85 & 119.38 & 80.12 & 1.49 & 61 & $\mathrm{CHCl}_{3}$ & [72] \\
\hline TOL & 8.9 & 18.24 & 92.14 & 105.91 & 0.87 & 111 & $\mathrm{C}_{7} \mathrm{H}_{8}$ & [71] \\
\hline DIO & 9.2 & 18.85 & 336.02 & 186.68 & 1.8 & 168 & $\mathrm{C}_{8} \mathrm{H}_{16} \mathrm{I}_{2}$ & [73] \\
\hline ODT & 9.1 & 18.65 & 178.36 & 183.92 & 0.97 & 269 & $\mathrm{C}_{8} \mathrm{H}_{18} \mathrm{~S}_{2}$ & [74] \\
\hline
\end{tabular}

${ }^{*}$ Note that, for calculating the $\chi_{i j}$ parameter in Equation (2), the CGS unit is used instead of the SI unit.

Figure 3 shows the phase diagrams of the ternary $\mathrm{CB} / \mathrm{P} 3 \mathrm{HT} / \mathrm{PC}_{61} \mathrm{BM}$ system at three different temperatures, (a) $298 \mathrm{~K}$, (b) $338 \mathrm{~K}$, and (c) $373 \mathrm{~K}$. Among these, Figure 3a displays two representative mechanisms for the L-L demixing processes, which are the nucleation and growth (NG) and the spinodal decomposition (SD) [54,55]. Importantly, as shown in Figure 3, the metastable and unstable regions (i.e., the miscibility gap) defined by the binodal and spinodal curves are diminished with increasing temperature. For example, the critical points were downshifted from the top vertex (CB) by exhibiting $\left(\phi_{1}^{c}, \phi_{2}^{c}, \phi_{3}^{c}\right)=(0.74$, $0.07,0.19)$ at $298 \mathrm{~K},(0.70,0.08,0.22)$ at $338 \mathrm{~K}$, and $(0.67,0.08,0.25)$ at $373 \mathrm{~K}$. Furthermore, if a linear relationship between $\phi_{2}^{c}$ and $T$ were assumed, the equation $\left(\phi_{2}^{c}=1.51972 \times 10^{-4}\right.$. $T+0.02682$ ) would be obtained through the linear fit (see Figure S1 in the Supplementary Materials (SM)). Hence, the phase behavior as a function of temperature indicates that the ternary system may show an upper critical solution temperature (UCST) phase behavior, as 
expected from most polymer solutions without any specific interaction such as hydrogen bonding. Figure $3 \mathrm{~d}$ shows a schematic explanation for the film-forming process from a ternary polymer solution according to the four cases displayed in Figure 3c. The first case indicates a homogenous $\mathrm{P} 3 \mathrm{HT} / \mathrm{PC}_{61} \mathrm{BM}$ phase, in which $\mathrm{PC}_{61} \mathrm{BM}$ molecules may be dissolved in the amorphous region of P3HT (i.e., forming a solid solution). The second describes an NG process in the P3HT-rich phase. The third displays a SD process. Finally, the fourth is an NG process again in the P3HT-lean phase although it is rarely probable due to a limited area in the diagram. Importantly, it is notable that, for OPV applications, most polymer / fullerene systems have the composition in the range of 'polymer: fullerene $=1: 0.8$ to 1:4' (hence, it may be included in Case 3). However, it is noteworthy that, although some amorphous polymer/fullerene systems $[34,46]$ were reported to contain circular domain structures in a film, if the OPV devices displayed that morphology, it indicates that those circular domains (e.g., $\mathrm{PC}_{61} \mathrm{BM}$ aggregation) might be electrically /physically interconnected within the charge hopping range (just like Case 3, allowing ambipolar transport in polymer/fullerene blend films). Furthermore, interestingly, Kim and Frisbie reported a metastable region $\left(\sim 30-50 \% \mathrm{PC}_{61} \mathrm{BM}\right)$ in the temperature-composition phase diagram for the binary $\mathrm{P} 3 \mathrm{HT} / \mathrm{PC}_{61} \mathrm{BM}$ system [35]. Here, the phase diagram of the ternary $\mathrm{CB} / \mathrm{P} 3 \mathrm{HT} / \mathrm{PC}_{61} \mathrm{BM}$ system reminisces the experimental results of Kim and Frisbie when $\phi_{\text {solvent }}=0$.
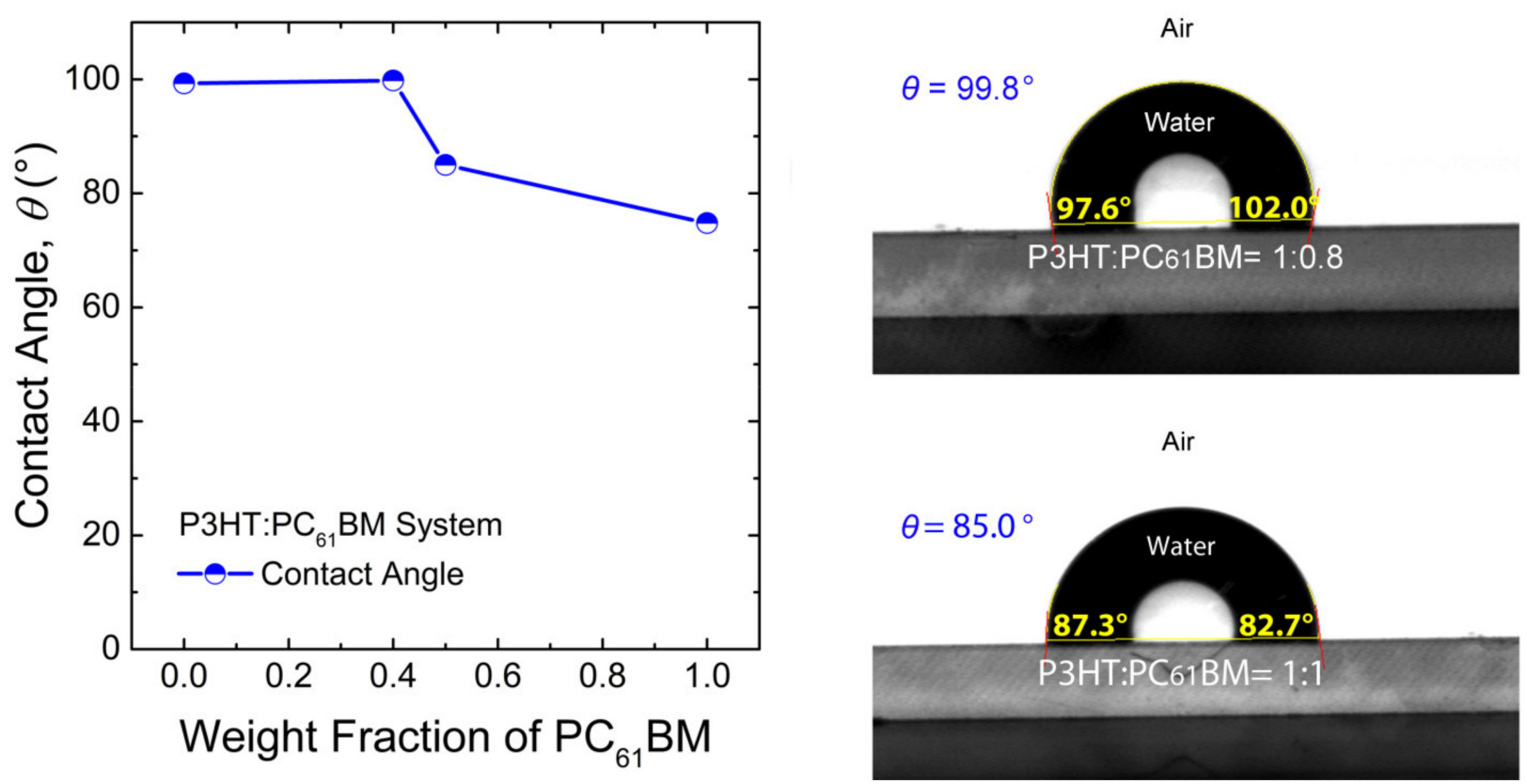

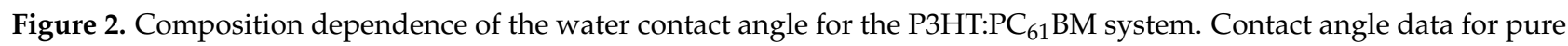
$\mathrm{P} 3 \mathrm{HT}$ and $\mathrm{PC}_{61} \mathrm{BM}$ could be found in our previous studies $[18,19]$. Note that the reported contact angle is the average value of the left and right angles.

Figure 4 shows the ternary phase diagrams when the $M_{n}$ of P3HT was increased from $22 \mathrm{~kg} / \mathrm{mol}$ (recall, Figure 3a) to $44 \mathrm{~kg} / \mathrm{mol}$ (Figure 4a) and then to $440 \mathrm{~kg} / \mathrm{mol}$ (Figure 4b), which explains the chain length effect on the phase behavior at $298 \mathrm{~K}$. As shown in Figure 4c, when $M_{n}$ was increased to more than $70 \mathrm{~kg} / \mathrm{mol}$, the critical point does not change significantly, indicating that the miscibility gap is less sensitive to the increase of $M_{n}$. Furthermore, as shown in Figure 4d, although the critical point is moved up with increasing $M_{n}$, both the binodal and spinodal curves almost overlap (Figure $4 \mathrm{~d}$ ). However, bear in mind that, although $\chi_{i j}$ could be a function of $M_{n}$, here it was assumed to be a constant. 
Table 3. Flory-Huggins interaction parameters and the molar volume ratios for the ternary systems.

\begin{tabular}{|c|c|c|c|c|c|}
\hline \multirow{2}{*}{ Ternary System } & \multicolumn{3}{|c|}{ Flory-Huggins Interaction Parameter * } & \multicolumn{2}{|c|}{ Molar Volume Ratio * } \\
\hline & $\chi_{12}$ & $\chi_{13}$ & $\chi_{23}$ & $s=v_{1} / v_{2}$ & $r=v_{1} / v_{3}$ \\
\hline $\mathrm{CB} / \mathrm{P} 3 \mathrm{HT} / \mathrm{PC}_{61} \mathrm{BM}$ & $32.7 \mathrm{~K} / \mathrm{T}+0.34$ & $165.4 \mathrm{~K} / T+0.34$ & $345.0 \mathrm{~K} / \mathrm{T}+0.34$ & 0.005071 & 0.167068 \\
\hline $\mathrm{CF} / \mathrm{P} 3 \mathrm{HT} / \mathrm{PC}_{61} \mathrm{BM}$ & $10.1 \mathrm{~K} / \mathrm{T}+0.34$ & $177.8 \mathrm{~K} / \mathrm{T}+0.34$ & $272.6 \mathrm{~K} / \mathrm{T}+0.34$ & 0.004006 & 0.131993 \\
\hline TOL/P3HT/PC 61 BM & $2.1 \mathrm{~K} / T+0.34$ & $307.0 \mathrm{~K} / T+0.34$ & $360.3 \mathrm{~K} / \mathrm{T}+0.34$ & 0.005296 & 0.174481 \\
\hline $\mathrm{DIO} / \mathrm{P} 3 \mathrm{HT} / \mathrm{PC}_{61} \mathrm{BM}$ & $23.5 \mathrm{~K} / \mathrm{T}+0.34$ & $414.3 \mathrm{~K} / T+0.34$ & $635.1 \mathrm{~K} / T+0.34$ & 0.009344 & 0.307858 \\
\hline $\mathrm{ODT} / \mathrm{P} 3 \mathrm{HT} / \mathrm{PC}_{61} \mathrm{BM}$ & $14.8 \mathrm{~K} / \mathrm{T}+0.34$ & $448.0 \mathrm{~K} / T+0.34$ & $625.7 \mathrm{~K} / \mathrm{T}+0.34$ & 0.009196 & 0.302998 \\
\hline $\mathrm{CB} / \mathrm{P} 3 \mathrm{HT} / \mathrm{PC}_{71} \mathrm{BM}$ & $32.7 \mathrm{~K} / \mathrm{T}+0.34$ & $147.5 \mathrm{~K} / \mathrm{T}+0.34$ & $319.0 \mathrm{~K} / \mathrm{T}+0.34$ & 0.005071 & 0.147613 \\
\hline CB/P3HT/ITIC & $32.7 \mathrm{~K} / \mathrm{T}+0.34$ & $270.0 \mathrm{~K} / T+0.34$ & $490.5 \mathrm{~K} / \mathrm{T}+0.34$ & 0.005071 & 0.071015 \\
\hline CB/PTB7/ITIC & $25.0 \mathrm{~K} / T+0.34$ & $270.0 \mathrm{~K} / T+0.34$ & $459.3 \mathrm{~K} / T+0.34$ & 0.001483 & 0.088029 \\
\hline $\begin{array}{l}\text { CB/PffBT4T- } \\
\text { 2OD/ITIC }\end{array}$ & $0.5 \mathrm{~K} / \mathrm{T}+0.34$ & $270.0 \mathrm{~K} / T+0.34$ & $294.0 \mathrm{~K} / T+0.34$ & 0.002448 & 0.088030 \\
\hline
\end{tabular}

${ }^{*}$ Note that the calculation methods are included in Supplementary Materials.

Figure 5 shows the phase diagrams of the ternary (a) $\mathrm{CF} / \mathrm{P} 3 \mathrm{HT} / \mathrm{PC}_{61} \mathrm{BM}$ and (b) $\mathrm{TOL} / \mathrm{P} 3 \mathrm{HT} / \mathrm{PC}_{61} \mathrm{BM}$ systems, describing the solvent effect on the phase behavior. Here the solubility parameters of solvents are $\delta_{1}=9.5(\mathrm{CB}), \delta_{1}=9.2(\mathrm{CF})$, and $\delta_{1}=8.9(\mathrm{TOL})$. Hence, considering $\delta_{2}=8.7(\mathrm{P} 3 \mathrm{HT})$ and $\delta_{3}=11.3\left(\mathrm{PC}_{61} \mathrm{BM}\right)$, we may estimate roughly the miscibility of the ternary system. As shown in Figures 3 and 5, the critical points are shifted from $\left(\phi_{1}^{c}, \phi_{2}^{c}, \phi_{3}^{c}\right)=(0.74,0.07,0.19)$ at $\mathrm{CB}$ to $(0.62,0.08,0.30)$ at $\mathrm{CF}$ and $(0.62,0.08,0.30)$ at TOL, indicating there is no simple trend owing to the various intermolecular interactions among the three components (see also Figure S2 in the Supplementary Materials). Furthermore, if we consider the molecular affinity between two components based on $\Delta \delta$, the $\mathrm{CB} / \mathrm{PC}_{61} \mathrm{BM}$ couples $(\Delta \delta=1.8)$ are more miscible than $\mathrm{CF} / \mathrm{PC}_{61} \mathrm{BM}(\Delta \delta=2.1)$, whereas the $\mathrm{CB} / \mathrm{P} 3 \mathrm{HT}$ $(\Delta \delta=0.8)$ are less miscible than $\mathrm{CF} / \mathrm{P} 3 \mathrm{HT}(\Delta \delta=0.5)$, indicating complicated interactions. However, it is notable that $\mathrm{CB}$ is more commonly used than the others (CF and TOL) in the OPV field because of its relatively high boiling point, $132{ }^{\circ} \mathrm{C}$, allowing polymer molecules to be more organized if time is given for crystallization. In the case of TOL, although the critical point is placed lowest from the top vertex, the binodal point is $(0.00$, $0.86,0.14)$ at $\delta_{1}=0$ suggesting that $\mathrm{PC}_{61} \mathrm{BM}$ will be easily phase-separated out from the P3HT matrix. Hence, it is very interesting to observe that, at the fixed $\chi_{23}$ value, the molecular miscibility/solubility of $\mathrm{P} 3 \mathrm{HT}$ and $\mathrm{PC}_{61} \mathrm{BM}$ components could be variable depending on the processing solvent (e.g., $\mathrm{CF}, \mathrm{TOL}$, and $\mathrm{CB}$ ) based on the prediction of Flory-Huggins theory for a ternary system. Furthermore, it is also noteworthy that, in a binary polymer/solvent system, if the third component, fullerene, is additionally incorporated into this solution, it could provide a phase-separation opportunity originating from the composition change, suggesting the usefulness of a ternary phase diagram.

In solution-processable photovoltaic fields, additive engineering is one of the typical methods for improving the morphology of an active layer for high efficiency OPV devices [47,73-77]. Figure 6 shows the phase diagrams of ternary (a) DIO/P3HT/PC ${ }_{61} \mathrm{BM}$ and (b) ODT/P3HT / $\mathrm{PC}_{61} \mathrm{BM}$ systems, in which DIO $\left(\delta_{1}=9.2\right)$ and ODT $\left(\delta_{1}=9.1\right)$ have the boiling point of $168{ }^{\circ} \mathrm{C}$ and $270{ }^{\circ} \mathrm{C}$, respectively. Interestingly, herein, when this additive (DIO or ODT) served as a solvent for $\mathrm{P} 3 \mathrm{HT}$ and $\mathrm{PC}_{61} \mathrm{BM}$, the Flory-Huggins theory predicted that $\mathrm{P} 3 \mathrm{HT}$ and $\mathrm{PC}_{61} \mathrm{BM}$ are almost immiscible with each other (the solubility limit of $\mathrm{PC}_{61} \mathrm{BM}$ is only $4 \%$ in this $\mathrm{P} 3 \mathrm{HT} / \mathrm{PC}_{61} \mathrm{BM}$ blend film) by exhibiting the binodal point $(0.00,0.96,0.04)$ at the $\mathrm{P}_{3 \mathrm{HT}} \mathrm{PC}_{61} \mathrm{BM}$ axis (see Figure 6$)$. This prediction suggests that the demixing process should be dependent on the choice of a solvent. However, note that this prediction was based on a specific condition, where the additive was used as a solvent for polymer and fullerene. Furthermore, another observation is that the areas defined by the spinodal curves are very wide, suggesting that it is highly probable that 
the polymer/fullerene blend should be phase separated in the unstable region through the spontaneous SD processes.

(a)

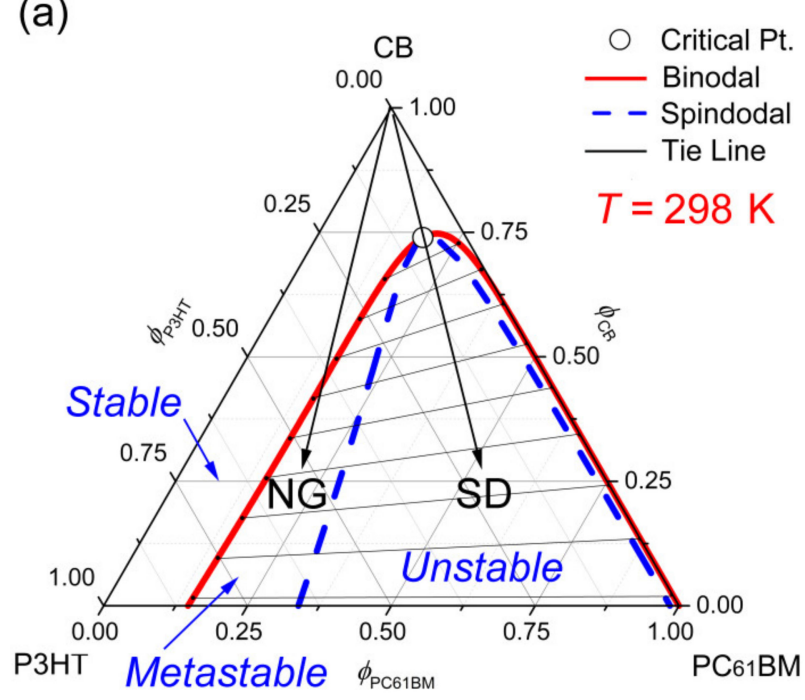

(c)

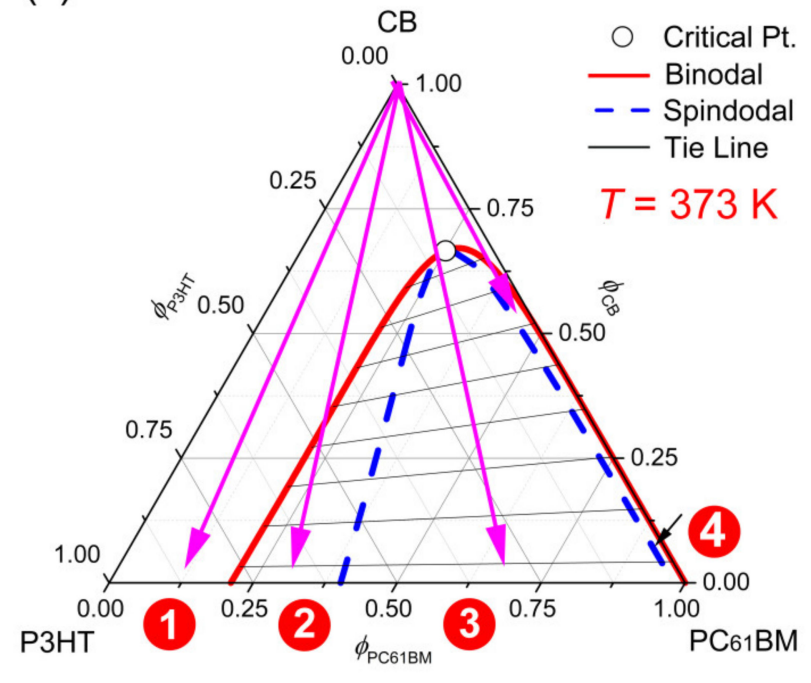

(b)

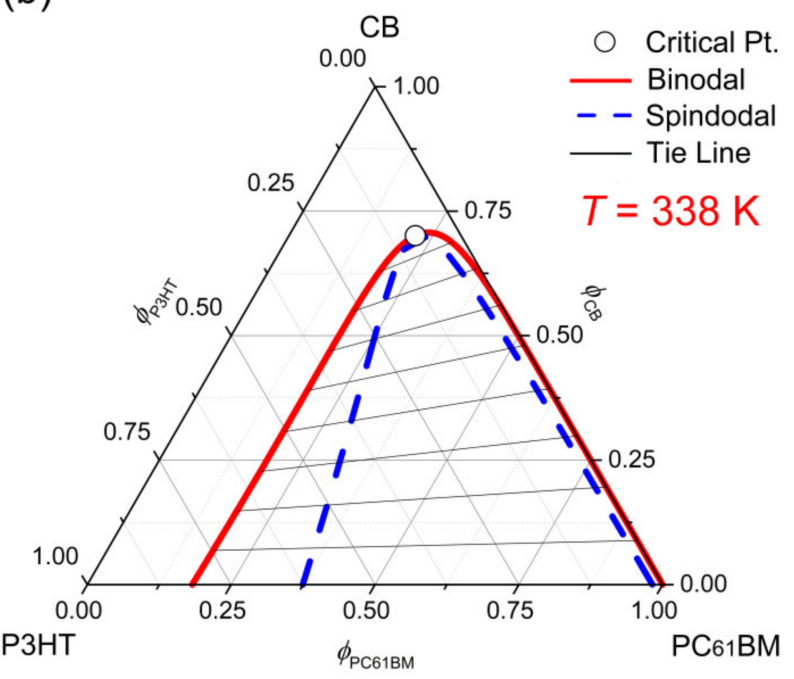

(d)
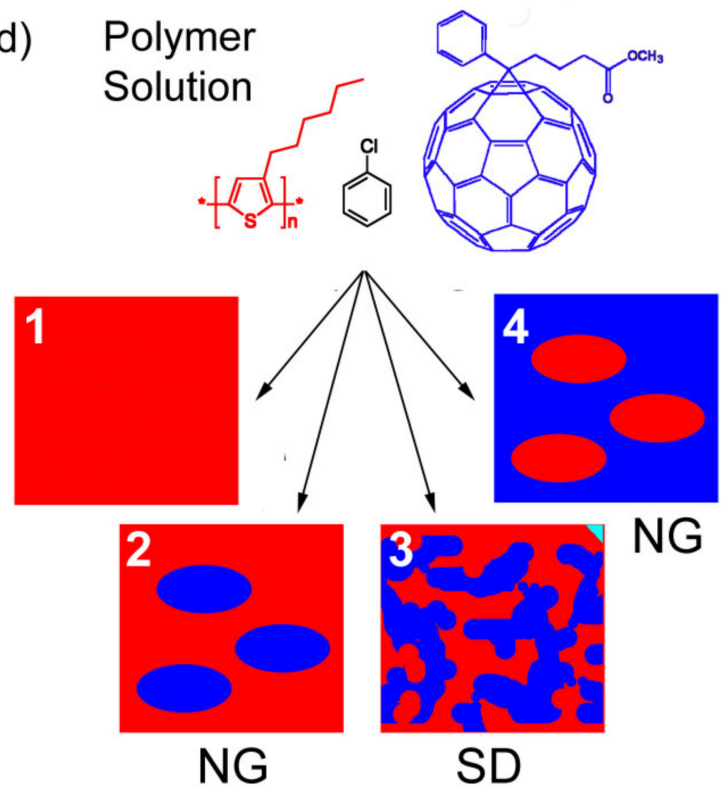

Figure 3. Phase diagrams for the ternary $\mathrm{CB} / \mathrm{P} 3 \mathrm{HT} / \mathrm{PC}_{61} \mathrm{BM}$ system as a function of temperature. (a) $T=298 \mathrm{~K}: \chi_{12}=0.45$, $\chi_{13}=0.90$, and $\chi_{23}=1.50 .(\mathbf{b}) T=338 \mathrm{~K}: \chi_{12}=0.44, \chi_{13}=0.83$, and $\chi_{23}=1.36$. (c) $T=373 \mathrm{~K}: \chi_{12}=0.43, \chi_{13}=0.78$, and $\chi_{23}=1.27$. Here, for P3HT, $M_{n}=22 \mathrm{~kg} / \mathrm{mol}, s=0.005071$ and $r=0.167068$. (d) A schematic explanation for a film-forming process through the four cases: (1) Single homogeneous phase. (2) Nucleation and growth of the polymer-rich phase. (3) Spinodal decomposition. (4) Nucleation and growth of the polymer-lean phase.

Next, the electron-acceptor effect on the phase behavior was studied for the ternary systems of (a) CB/P3HT/PC 71 BM and (b) CB/P3HT/ITIC. Here, $\mathrm{PC}_{71} \mathrm{BM}$ has $\delta_{3}=11.2$ whereas ITIC has $\delta_{3}=11.8$, indicating that ITIC should be less miscible with P3HT $\left(\delta_{2}=8.7\right)$ or $\mathrm{CB}\left(\delta_{1}=9.5\right)$ than $\mathrm{PC}_{71} \mathrm{BM}$. Indeed, Figure 7 clearly exhibits that the ITIC-incorporated ternary system is less miscible than the one that incorporated $\mathrm{PC}_{71} \mathrm{BM}$. However, bear in mind that the predicted results in Figure 7 are only for the case of a specific polymer, P3HT. In other words, if the polymer is replaced by another, the trend of the results will be changed accordingly, depending on the solubility parameter $\delta_{2}$. 
(a)

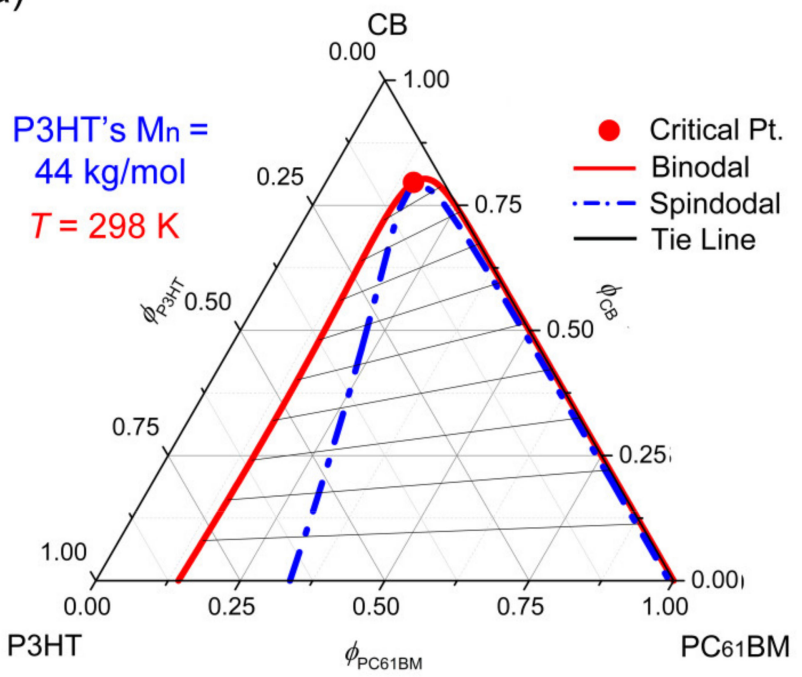

(c)

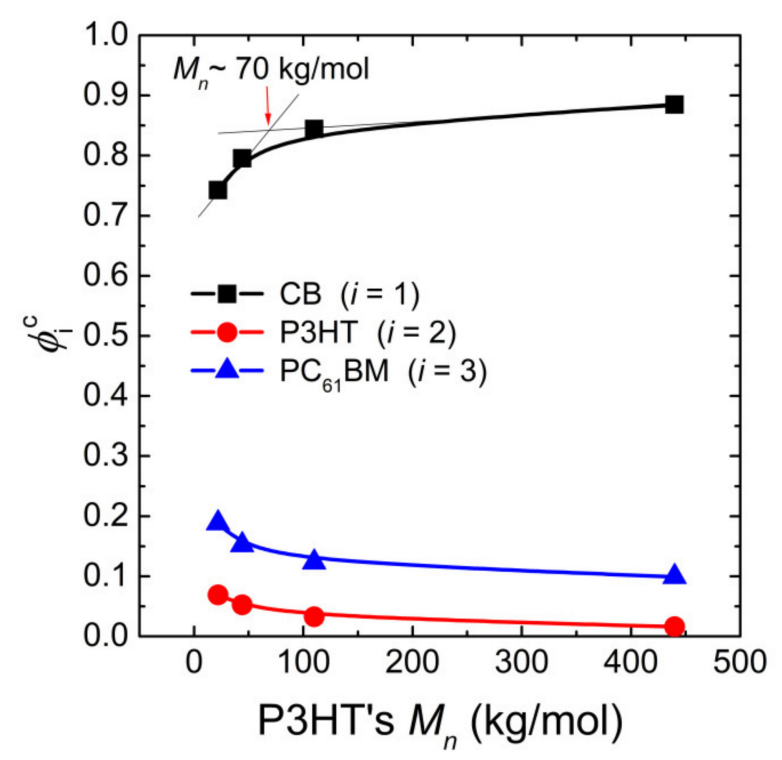

(b)

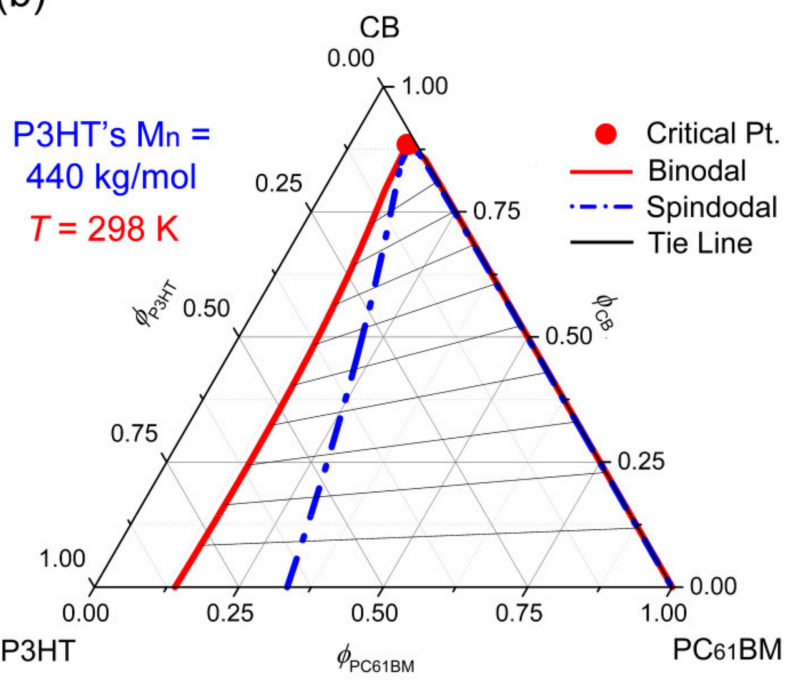

(d)

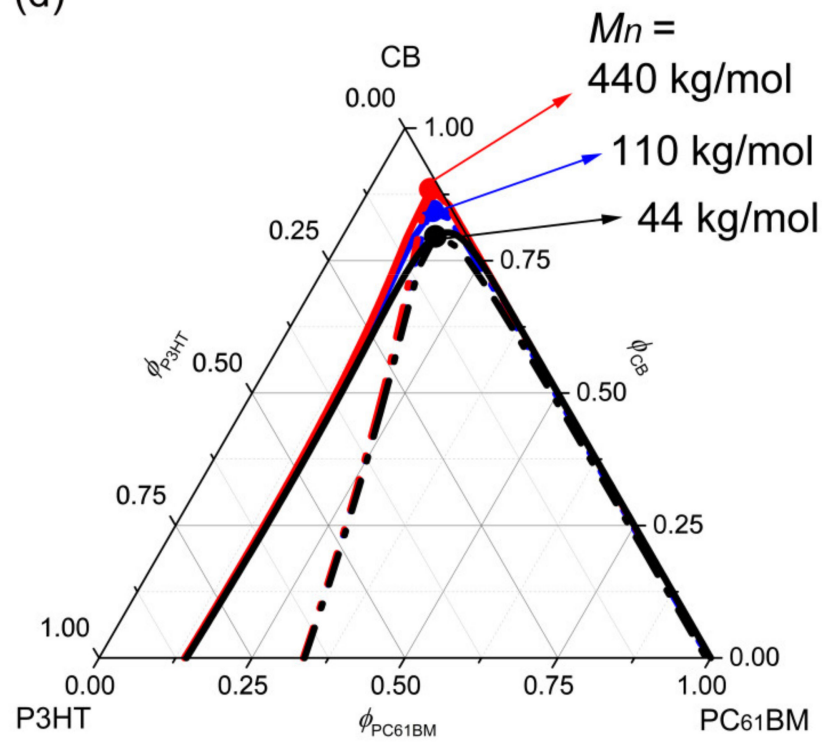

Figure 4. Phase diagrams for the ternary $\mathrm{CB} / \mathrm{P} 3 \mathrm{HT} / \mathrm{PC}_{61} \mathrm{BM}$ system as a function of the molecular weight of $\mathrm{P} 3 \mathrm{HT}$, when $\chi_{12}=0.45, \chi_{13}=0.90$, and $\chi_{23}=1.50$ at constant $\mathrm{T}=298 \mathrm{~K}:(\mathbf{a}) \mathrm{P}_{3} \mathrm{HT}^{\prime} \mathrm{s} \mathrm{M}_{\mathrm{n}}=44 \mathrm{~kg} / \mathrm{mol}, \mathrm{s}=0.002535$, and $\mathrm{r}=0.167068$, and (b) $\mathrm{P}_{3} \mathrm{HT}^{\prime} \mathrm{s} \mathrm{M}_{\mathrm{n}}=440 \mathrm{~kg} / \mathrm{mol}, \mathrm{s}=0.000254$, and $\mathrm{r}=0.167068$. (c) Critical point $\left(\phi_{1}^{c}, \phi_{2}^{c}, \phi_{3}^{c}\right)$ of the ternary CB $/ \mathrm{P} 3 \mathrm{HT} / \mathrm{PC}_{61} \mathrm{BM}$ system as a function of molecular weight. (d) Comparison of the three phase diagrams with different Mn. Note that, when P3HT has $\mathrm{M}_{\mathrm{n}}=110 \mathrm{~kg} / \mathrm{mol}$, the physical quantities $(\mathrm{s}=0.001014$ and $\mathrm{r}=0.167068)$ are used for calculating the ternary phase diagram. 
(a)

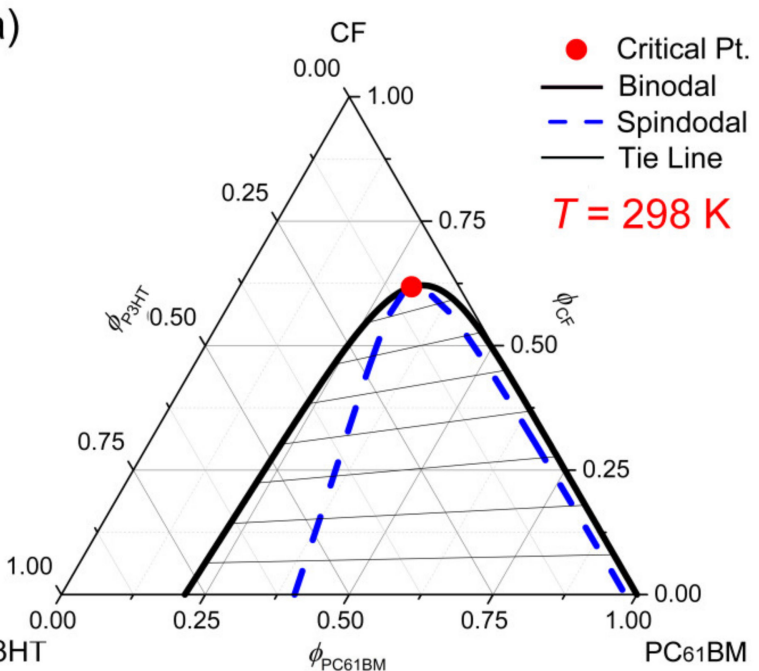

(b)

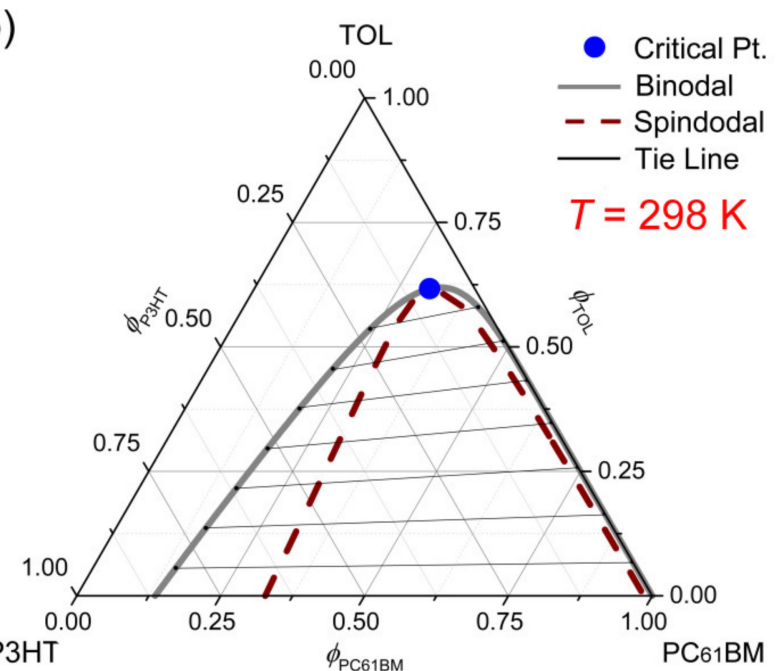

Figure 5. Phase diagrams for the ternary system at constant $\mathrm{T}=298 \mathrm{~K}$. (a) $\mathrm{CF} / \mathrm{P} 3 \mathrm{HT} / \mathrm{PC} 61 \mathrm{BM}: \chi_{12}=0.37, \chi_{13}=0.95$, $\chi_{23}=0.92, \mathrm{~s}=0.004006$ and $\mathrm{r}=0.131993$. (b) TOL $/ \mathrm{P} 3 \mathrm{HT} / \mathrm{PC}_{61} \mathrm{BM}: \chi_{12}=0.35, \chi_{13}=1.37, \chi_{23}=1.55, \mathrm{~s}=0.005296$ and $\mathrm{r}=0.174481$. Here, CF and TOL represent chloroform and toluene, respectively.

(a)

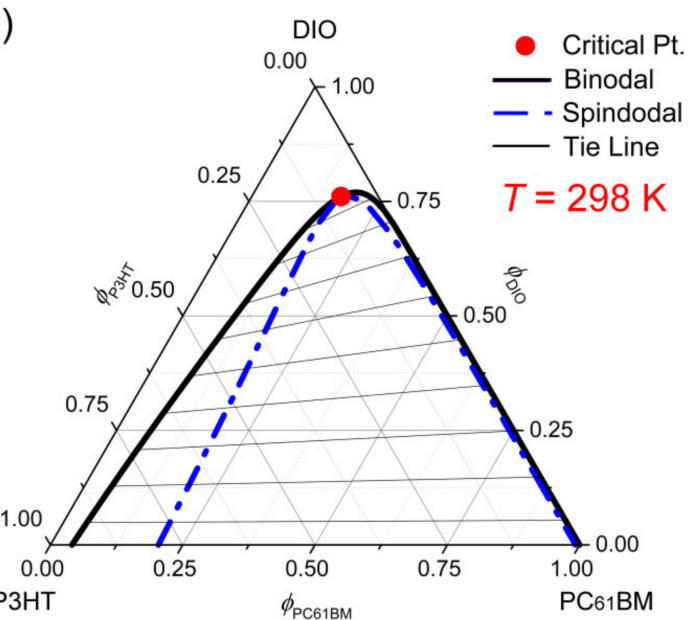

(b)

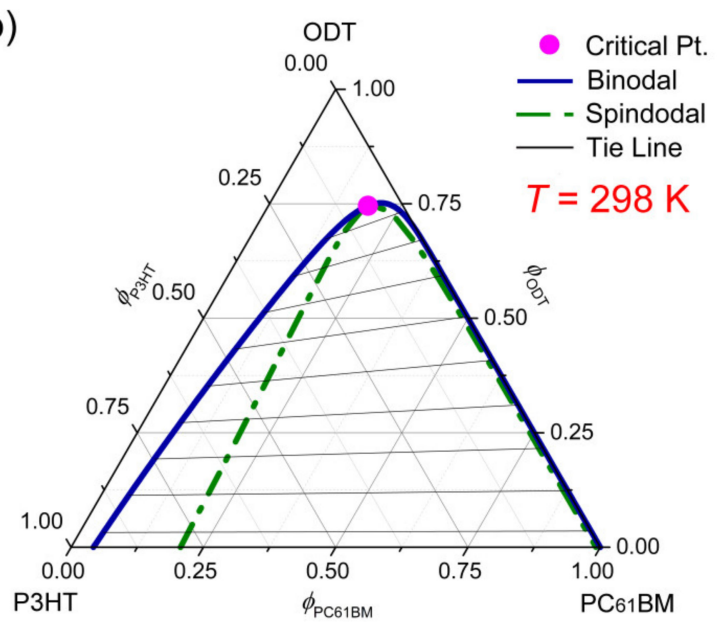

Figure 6. Phase diagrams of the ternary systems at constant $T=298 \mathrm{~K}$. (a) DIO/P3HT/PC 61 BM: $\chi_{12}=0.42, \chi_{13}=1.73$, $\chi_{23}=2.47, s=0.009344$ and $r=0.307858$. (b) ODT $/$ P3HT $/ \mathrm{PC}_{61} \mathrm{BM}: \chi_{12}=0.39, \chi_{13}=1.84, \chi_{23}=2.44, s=0.009196$ and $r=0.302998$. Here DIO and ODT stand for 1,8-diiodooctane and 1,8-octandithiol, respectively.

Finally, the high-performance conjugated polymers such as PTB7 $\left(\delta_{2}=8.8\right)$ and PffBT4T-2OD $\left(\delta_{2}=9.4\right)$ were investigated by mixing one of these polymers with ITIC $\left(\delta_{3}=11.8\right)$ and $\mathrm{CB}\left(\delta_{1}=9.5\right)$. Here, it is notable that PffBT4T-2OD has a very similar solubility parameter with $\mathrm{CB}$, forecasting a favorable miscibility between PffBT4T-2OD and CB. Indeed, as shown in Figure 8, the miscibility gap is very small in the CB/PffBT4T-2OD/ITIC system, whereas it is very large in CB/PTB7/ITIC as expected from $\delta_{i}$ parameters. 
(a)

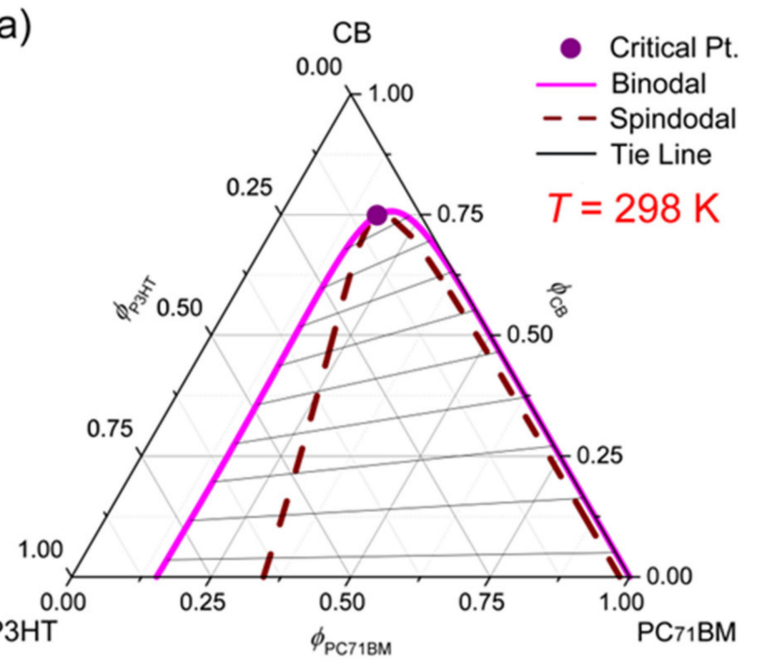

(b)

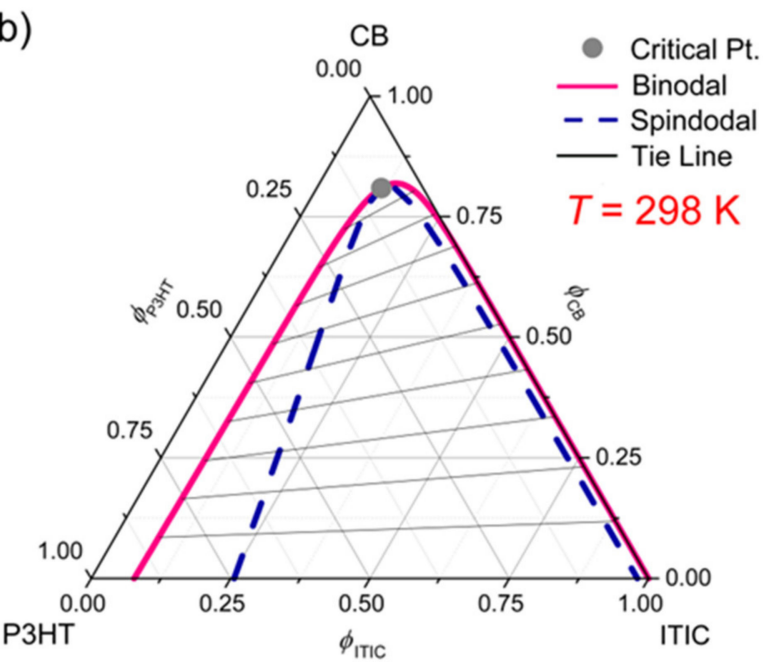

Figure 7. Phase diagrams for ternary systems at constant $T=298 \mathrm{~K}$. (a) CB/P3HT/PC 71 BM: $\chi_{12}=0.45, \chi_{13}=0.84$, $\chi_{23}=1.41, s=0.005071$ and $r=0.147613$. (b) CB/P3HT/ITIC: $\chi_{12}=0.45, \chi_{13}=1.25, \chi_{23}=1.99, s=0.005071$ and $r=0.071015$.

(a)

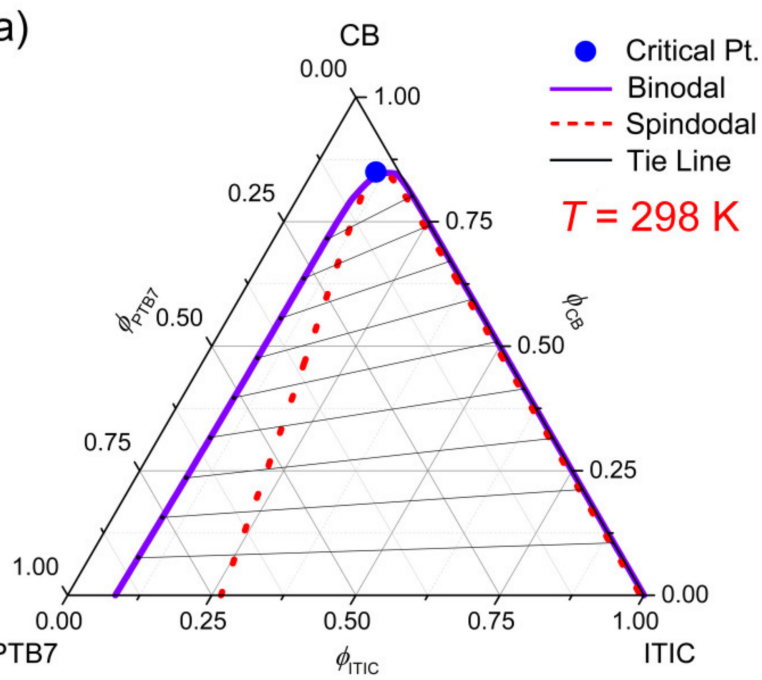

(b)

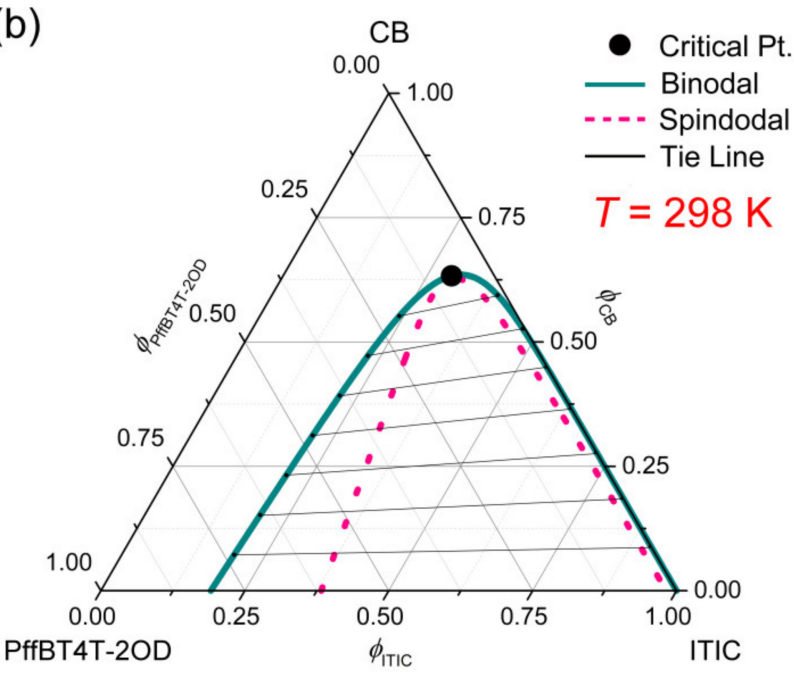

Figure 8. Phase diagrams for the ternary systems at constant $T=298 \mathrm{~K}$. (a) CB/PTB7/ITIC: $\chi_{12}=0.42, \chi_{13}=1.25$, $\chi_{23}=1.88, s=0.001267$ and $r=0.088029$. (b) CB/PffBT4T-2OD/ITIC: $\chi_{12}=0.34, \chi_{13}=1.25, \chi_{23}=1.33, s=0.002448$ and $r=0.088030$.

\section{Conclusions}

The phase diagrams of ternary $\pi$-conjugated polymer solutions were constructed as a function of temperature, molecular weight, solvent species, additive, and electron acceptor. Then, our investigation was extended to the high-performance low bandgap polymers such as PTB7 and PffBT4T-2OD (PCE-11). Through this study, the results indicate: (1) The miscibility gap decreases with increasing temperature, suggesting an upper critical solution temperature (UCST) phase behavior as expected from polymer solutions without specific interactions. (2) If the $M_{n}$ of P3HT is increased to more than $70 \mathrm{~kg} / \mathrm{mol}$, the miscibility gap does not change much with increasing $M_{n}$. (3) Among three solvents (CB, CF, TOL) tested, the chloroform displayed the smallest demixing area in the ternary phase diagram. (4) When the two additives, 1,8-diiodooctane (DIO) and 1,8-octanedithiol (ODT), were employed as a solvent in the ternary $\mathrm{DIO}(\mathrm{ODT}) / \mathrm{P} 3 \mathrm{HT} / \mathrm{PC}_{61} \mathrm{BM}$ systems, the miscibility gap was much more enlarged, indicating that these additives promoted immiscibility between 
$\mathrm{P} 3 \mathrm{HT}$ and $\mathrm{PC}_{61} \mathrm{BM}$. (5) If the electron-donating polymer is $\mathrm{P} 3 \mathrm{HT}$, the nonfullerene acceptor ITIC has a less miscibility with $\mathrm{P} 3 \mathrm{HT}$ than does the fullerene acceptor (i.e., $\mathrm{PC}_{61} \mathrm{BM}$ or $\mathrm{PC}_{71} \mathrm{BM}$ ). (6) Among the three polymers (P3HT, PTB7, and PffBT4T-2OD), the low bandgap PffBT4T-2OD polymer has the best miscibility with ITIC, demonstrating the smallest miscibility gap. Hence, our systematic study may provide a rational understanding for the demixing processes of ternary $\pi$-conjugated polymer solutions based on the cross talk between polymer photovoltaics and molecular thermodynamics. Finally, our future works may include the experimental demonstration of phase separation mechanism for the amorphous polymer/amorphous NFA, semicrystalline polymer/amorphous NFA, amorphous polymer/crystalline NFA, and semicrystalline polymer/crystalline NFA solutions from the ternary phase behavior point of view.

Supplementary Materials: The following are available online at https:/ /www.mdpi.com/2073-4 360/13/6/983/s1, Calculation methods: the Flory-Huggins interaction parameter and the relative molar volume for the $\mathrm{CB} / \mathrm{P} 3 \mathrm{HT} / \mathrm{PC}_{61} \mathrm{BM}$ system as an example. Figure S1a: Critical point $\left(\phi_{1}^{c}, \phi_{2}^{c}\right.$, $\phi_{3}^{c}$ ) of the ternary CB-P3HT-PC 61 BM system as a function of temperature. (b) Linear fit for the plot of $\phi_{2}^{c}(\mathrm{P} 3 \mathrm{HT})$ vs. temperature: $\phi_{2}^{c}=1.51972 \times 10-4 \cdot \mathrm{T}+0.02682$. Figure S2a: Critical point $\left(\phi_{1}^{c}, \phi_{2}^{c}, \phi_{3}^{c}\right)$ of the ternary Solvent/ $\mathrm{P} 3 \mathrm{HT} / \mathrm{PC}_{61} \mathrm{BM}$ system as a function of solvent species $(\mathrm{CB}, \mathrm{CF}$, and $\mathrm{TOL})$. $\mathrm{CB}$, $\mathrm{CF}$, and TOL stand for chlorobenzene, chloroform, and toluene, respectively. (b) The plot of $\phi_{2}^{c}$ vs. $\delta_{1}$ for clarifying the indistinguishable data shown in Figure S2a.

Author Contributions: Conceptualization, investigation, data curation, writing-original draft preparation, writing - review and editing, J.Y.K. The author has read and agreed to the published version of the manuscript.

Funding: This research received no external funding.

Institutional Review Board Statement: Not applicable.

Informed Consent Statement: Not applicable.

Data Availability Statement: The data presented in this study are available on request from the corresponding author.

Acknowledgments: We thank Timothy Kwa for contributing to the scientific discussion on this manuscript.

Conflicts of Interest: The author declares no conflict of interest.

\section{References}

1. Flory, P.J. Thermodynamics of High Polymer Solutions. J. Chem. Phys. 1942, 10, 51-61. [CrossRef]

2. Huggins, M.L. Some Properties of Solutions of Long-chain Compounds. J. Phys. Chem. 1942, 46, 151-158. [CrossRef]

3. Flory, P.J. Principles of Polymer Chemistry; Cornell University Press: Ithaca, NY, USA, 1953.

4. Scott, R.A. The Thermodynamics of High Polymer Solutions. V. Phase Equilibria in the Ternary System: Polymer 1—Polymer 2-Solvent. J. Chem. Phys. 1949, 17, 279-284. [CrossRef]

5. Tompa, H. Phase relationships in polymer solutions. Trans. Faraday Soc. 1949, 45, 1142-1152. [CrossRef]

6. Tompa, H. Polymer Solutions; Academic Press: Cambridge, MA, USA, 1956.

7. Loeb, S.; Sourirajan, S. Sea Water Demineralization by Means of an Osmotic Membrane. Adv. Chem. Ser. 1963, 38, 117-132. [CrossRef]

8. Wienk, I.M.; Boom, R.M.; Beerlage, M.A.M.; Bulte, A.M.W.; Smolders, C.A.; Strathmann, H. Recent advances in the formation of phase inversion membranes made from amorphous or semi-crystalline polymers. J. Membr. Sci. 1996, 113, 361-371. [CrossRef]

9. Guillen, G.R.; Pan, Y.; Li, M.; Hoek, M.V. Preparation and Characterization of Membranes Formed by Nonsolvent Induced Phase Separation: A Review. Ind. Eng. Chem. Res. 2011, 50, 3798-3817. [CrossRef]

10. Altena, F.W.; Smolders, C.A. Calculation of liquid-liquid phase separation in a ternary system of a polymer in a mixture of a solvent and a nonsolvent. Macromolecules 1982, 15, 1491-1497. [CrossRef]

11. Yilmaz, L.; McHugh, A.J. Analysis of nonsolvent-solvent-polymer phase diagrams and their relevance to membrane formation modeling. J. Appl. Polym. Sci. 1986, 31, 997-1018. [CrossRef]

12. Qian, C.; Mumby, S.J.; Eichinger, B.E. Phase diagrams of binary polymer solutions and blends. Macromolecules 1991, 24, 1655-1661. [CrossRef]

13. Hu, Y.; Ying, X.; Wu, D.T.; Prausnitz, J.M. Continuous thermodynamics for polydisperse polymer solutions. Fluid Phase Equilibria 1995, 104, 229-252. [CrossRef] 
14. Flory, P.J. Fifteenth Spiers Memorial Lecture. Thermodynamics of polymer solutions. Discuss. Faraday Soc. 1970, 49, 7-29. [CrossRef]

15. Hsu, C.C.; Prausnitz, J.M. Thermodynamics of Polymer Compatibility in Ternary Systems. Macromolecules 1974, 7, 320-324. [CrossRef]

16. Bates, F.S. Polymer-Polymer Phase Behavior. Science 1991, 251, 898-905. [CrossRef]

17. Hellebust, S.; Nilsson, S.; Blokhus, A.M. Phase Behavior of Anionic Polyelectrolyte Mixtures in Aqueous Solution. Effects of Molecular Weights, Polymer Charge Density, and Ionic Strength of Solution. Macromolecules 2003, 36, 5372-5382. [CrossRef]

18. Kim, J.Y. Order-Disorder Phase Equilibria of Regioregular Poly(3-hexylthiophene-2,5-diyl) Solution. Macromolecules 2018, 51, 9026-9034. [CrossRef]

19. Kim, J.Y. Phase Diagrams of Binary Low Bandgap Conjugated Polymer Solutions and Blends. Macromolecules 2019, 52, 4317-4328. [CrossRef]

20. Shirakawa, H.; Louis, E.J.; MacDiarmid, A.G.; Chiang, C.K.; Heeger, A.J. Synthesis of electrically conducting organic polymers: Halogen derivatives of polyacetylene, $(\mathrm{CH})$ x. J. Chem. Soc. Chem. Commun. 1977, 578-580. [CrossRef]

21. Chiang, C.K.; Fincher, C.R., Jr.; Park, Y.W.; Heeger, A.J.; Shirakawa, H.; Louis, E.J.; Gau, S.C.; MacDiarmid, A.G. Electrical Conductivity in Doped Polyacetylene. Phys. Rev. Lett. 1977, 39, 1098-1101. [CrossRef]

22. Heeger, A.J. Semiconducting and Metallic Polymers: The Fourth Generation of Polymeric Materials (Nobel Lecture). Angezw. Chem. Int. Ed. 2001, 40, 2591-2611. [CrossRef]

23. Sariciftci, N.S.; Smilowitz, L.; Heeger, A.J.; Wudl, F. Photoinduced Electron Transfer from a Conducting Polymer to Buckminsterfullerene. Science 1992, 258, 1474-1476. [CrossRef] [PubMed]

24. Halls, J.J.M.; Walsh, C.A.; Greenham, N.C.; Marseglia, E.A.; Friend, R.H.; Moratti, S.C.; Holmes, A.B. Efficient photodiodes from interpenetrating polymer networks. Nature 1995, 376, 498-500. [CrossRef]

25. Yu, G.; Gao, J.; Hummelen, J.C.; Wudl, F.; Heeger, A.J. Polymer Photovoltaic Cells: Enhanced Efficiencies via a Network of Internal Donor-Acceptor Heterojunctions. Science 1995, 270, 1789-1791. [CrossRef]

26. Mikhnenko, O.V.; Blom, P.W.M.; Nguyen, T.-Q. Exciton diffusion in organic semiconductors. Energy Environ. Sci. 2015, 8, 1867-1888. [CrossRef]

27. Tamai, Y.; Ohkita, H.; Benten, H.; Ito, S. Exciton Diffusion in Conjugated Polymers: From Fundamental Understanding to Improvement in Photovoltaic Conversion Efficiency. J. Phys. Chem. Lett. 2015, 6, 3417-3428. [CrossRef] [PubMed]

28. Firdaus, Y.; Le Corre, V.M.; Karuthedath, S.; Liu, W.; Markina, A.; Huang, W.; Chattopadhyay, S.; Nahid, M.M.; Nugraha, M.I.; Lin, Y.; et al. Long-range exciton diffusion in molecular non-fullerene acceptors. Nat. Commun. 2020, 11, 5220. [CrossRef] [PubMed]

29. Vogelsang, J.; Adachi, T.; Brazard, J.; Vanden Bout, D.A.; Barbara, P.F. Self-assembly of highly ordered conjugated polymer aggregates with long-range energy transfer. Nat. Mater. 2011, 10, 942-946. [CrossRef]

30. Jin, X.-H.; Price, M.B.; Finnegan, J.R.; Boott, C.E.; Richter, J.M.; Rao, A.; Menke, S.M.; Friend, R.H.; Whittell, G.R.; Manners, I. Long-range exciton transport in conjugated polymer nanofibers prepared by seeded growth. Science 2018, 360, 897-900. [CrossRef]

31. Hoppe, H.; Sariciftci, N.S. Morphology of polymer/fullerene bulk heterojunction solar cells. J. Mater. Chem. 2006, 16, 45-61. [CrossRef]

32. Moule, A.J.; Meerholtz, K. Morphology Control in Solution-Processed Bulk-Heterojunction Solar Cell Mixtures. Adv. Funct. Mater. 2009, 19, 3028-3036. [CrossRef]

33. Richter, L.J.; Delongchamp, D.M.; Amassian, A. Morphology Development in Solution-Processed Functional Organic Blend Films: An In Situ Viewpoint. Chem. Rev. 2017, 117, 6332-6366. [CrossRef]

34. Nilsson, S.; Bernasik, A.; Budkowski, A.; Moons, E. Morphology and Phase Segregation of Spin-Casted Films of Polyfluorene/PCBM Blends. Macromolecules 2007, 40, 8291-8301. [CrossRef]

35. Kim, J.Y.; Frisbie, C.D. Correlation of Phase Behavior and Charge Transport in Conjugated Polymer/Fullerene Blends. J. Phys. Chem. C 2008, 112, 17726-17736. [CrossRef]

36. Müller, C.; Ferenczi, T.A.M.; Campoy-Quiles, M.; Frost, J.M.; Bradley, D.D.C.; Smith, P.; Stingelin-Stutzmann, N.; Nelson, J. Binary Organic Photovoltaic Blends: A Simple Rationale for Optimum Compositions. Adv. Mater. 2008, 20, 3510-3515. [CrossRef]

37. Zhao, J.; Swinnen, Z.; Van Assche, G.; Manca, J.; Vanderzande, D.; Van Mele, B. Phase Diagram of P3HT/PCBM Blends and Its Implication for the Stability of Morphology. J. Phys. Chem. B 2009, 113, 1587-1591. [CrossRef]

38. Ballantyne, A.M.; Ferenczi, T.A.; Campoy-Quiles, M.; Clarke, T.M.; Maurano, A.; Wong, K.H.; Zhang, W.; Stingelin-Stutzmann, N.; Kim, J.-S.; Bradley, D.D.; et al. Understanding the Influence of Morphology on Poly(3-hexylselenothiophene):PCBM Solar Cells. Macromolecules 2010, 43, 1169-1174. [CrossRef]

39. Kozub, D.R.; Vakhshouri, K.; Orme, L.M.; Wang, C.; Hexemer, A.; Gomez, E.D. Polymer Crystallization of Partially Miscible Polythiophene/Fullerene Mixtures Controls Morphology. Macromolecules 2011, 44, 5722-5726. [CrossRef]

40. Nicolet, C.; Deribew, D.; Renaud, C.; Fleury, G.; Brochon, C.; Cloutet, E.; Vignau, L.; Wantz, G.; Cramail, H.; Geoghegan, M.; et al. Optimization of the Bulk Heterojunction Composition for Enhanced Photovoltaic Properties: Correlation between the Molecular Weight of the Semiconducting Polymer and Device Performance. J. Phys. Chem. B 2011, 115, 12717-12727. [CrossRef] [PubMed]

41. Müller, C.; Bergqvist, J.; Vandewal, K.; Tvingstedt, K.; Anselmo, A.S.; Magnusson, R.; Alonso, M.I.; Moons, E.; Arwin, H.; Campoy-Quiles, M.; et al. Phase behaviour of liquid-crystalline polymer/fullerene organic photovoltaic blends: Thermal stability and miscibility. J. Mater. Chem. 2011, 21, 10676-10684. [CrossRef] 
42. Miller, N.C.; Gysel, R.; Miller, C.E.; Verploegen, E.; Beiley, Z.; Heeney, M.; McCulloch, I.; Bao, Z.; Toney, M.F.; McGehee, M.D. The phase behavior of a polymer-fullerene bulk heterojunction system that contains bimolecular crystals. J. Polym. Sci. B Polym. Phys. 2011, 49, 499-503. [CrossRef]

43. Li, N.; Machui, F.; Waller, D.; Koppe, M.; Brabec, C.J. Determination of phase diagrams of binary and ternary organic semiconductor blends for organic photovoltaic devices. Sol. Energy Mater. Sol. Cells 2011, 95, 3465-3471. [CrossRef]

44. Li, N.; Perea, J.D.; Kassar, T.; Richter, M.; Heumueller, T.; Matt, G.J.; Hou, Y.; Güldal, N.S.; Chen, H.; Chen, S.; et al. Abnormal strong burn-in degradation of highly efficient polymer solar cells caused by spinodal donor-acceptor demixing. Nat. Commun. 2017, 8, 14541. [CrossRef]

45. Ghasemi, M.; Hu, H.; Peng, Z.; Rech, J.J.; Angunawela, I.; Carpenter, J.H.; Stuard, S.J.; Wadsworth, A.; McCulloch, I.; You, W.; et al. Delineation of Thermodynamic and Kinetic Factors that Control Stability in Non-fullerene Organic Solar Cells. Joule 2019, 3, 1-21. [CrossRef]

46. Kouijzer, S.; Michels, J.J.; Van den Berg, M.; Gevaerts, V.S.; Turbiez, M.; Wienk, M.M.; Janssen, R.A.J. Predicting Morphologies of Solution Processed Polymer:Fullerene Blends. J. Am. Chem. Soc. 2013, 135, 12057-12067. [CrossRef] [PubMed]

47. Shao, M.; Keum, J.K.; Kumar, R.; Chen, J.; Browning, J.F.; Das, S.; Chen, W.; Hou, J.; Do, C.; Littrell, K.C.; et al. Understanding How Processing Additives Tune the Nanoscale Morphology of High Efficiency Organic Photovoltaic Blends: From Casting Solution to Spun-Cast Thin Film. Adv. Funct. Mater. 2014, 24, 6647-6657. [CrossRef]

48. Michels, J.; Moons, E. Simulation of Surface-Directed Phase Separation in a Solution-Processed Polymer/PCBM Blend. Macromolecules 2013, 46, 8693-8701. [CrossRef]

49. Schaefer, C.; Michels, J.J.; Van Der Schoot, P. Structuring of Thin-Film Polymer Mixtures upon Solvent Evaporation. Macromolecules 2016, 49, 6858-6870. [CrossRef]

50. Kim, J.-H.; Gadisa, A.; Schaefer, C.; Yao, H.; Gautam, B.R.; Balar, N.; Ghasemi, M.; Constantinou, I.; So, F.; O'Connor, B.T.; et al. Strong polymer molecular weight-dependent material interactions: Impact on the formation of the polymer/fullerene bulk heterojunction morphology. J. Mater. Chem. A 2017, 5, 13176-13188. [CrossRef]

51. Bokel, F.A.; Engmann, S.; Herzing, A.A.; Collins, B.A.; Ro, H.W.; DeLongchamp, D.M.; Richter, L.J.; Schaible, E.; Hexemer, A. In Situ X-ray Scattering Studies of the Influence of an Additive on the Formation of a Low-Bandgap Bulk Heterojunction. Chem. Mater. 2017, 29, 2283-2293. [CrossRef]

52. Negi, V.; Wodo, O.; Van Franeker, J.J.; Janssen, R.A.J.; Bobbert, P.A. Simulating Phase Separation during Spin Coating of a Polymer-Fullerene Blend: A Joint Computational and Experimental Investigation. ACS Appl. Energy Mater. 2018, 1, 725-735. [CrossRef]

53. Xin, J.; Meng, X.; Xu, X.; Zhu, Q.; Naveed, B.; Ma, W. Cold Crystallization Temperature Correlated Phase Separation, Performance, and Stability of Polymer Solar Cells. Matter 2019, 1, 1-15. [CrossRef]

54. Cahn, J.W. Phase Separation by Spinodal Decomposition in Isotropic Systems. J. Chem. Phys. 1965, 42, 93-99. [CrossRef]

55. Favvas, E.P.; Mitropoulos, A.C. What is spinodal decomposition? J. Eng. Sci. Technol. Rev. 2008, 1, 25-37. [CrossRef]

56. Van de Witte, P.; Dijkstra, P.J.; Van den Berg, J.W.A.; Feijen, J. Phase separation processes in polymer solutions in relation to membrane formation. J. Membr. Sci. 1996, 117, 1-31. [CrossRef]

57. Vaynzof, Y.; Kabra, D.; Zhao, L.; Chua, L.L.; Steiner, U.; Friend, R.H. Surface-Directed Spinodal Decompositionin Poly[3 -hexylthiophene] and C61-Butyric Acid Methyl Ester Blends. ACS Nano 2011, 5, 329-336. [CrossRef]

58. McNeill, C.R.; Greenham, N.C. Conjugated-Polymer Blends for Optoelectronics. Adv. Mater. 2009, 21, 3840-3850. [CrossRef]

59. Campoy-Quiles, M.; Ferenczi, T.; Agostinelli, T.; Etchegoin, P.G.; Kim, Y.; Anthopoulos, T.D.; Stavrinou, P.N.; Bradley, D.D.C.; Nelson, J. Morphology evolution via self-organization and lateral and vertical diffusion in polymer:fullerene solar cell blends. Nat. Mater. 2008, 7, 158-164. [CrossRef]

60. Natta, G.; Corradini, P. Conformation of linear chains and their mode of packing in the crystal state. J. Polym. Sci. 1959, 39, 29-46. [CrossRef]

61. Kim, J.Y.; Cho, H.; Noh, S.; Lee, Y.; Nam, Y.M.; Lee, C.; Jo, W.H. Charge transport in amorphous low bandgap conjugated polymer/fullerene films. J. Appl. Phys. 2012, 111, 043710. [CrossRef]

62. Lin, Y.; Wang, J.; Zhang, Z.-G.; Bai, H.; Li, Y.; Zhu, D.; Zhan, X. An Electron Acceptor Challenging Fullerenes for Efficient Polymer Solar Cells. Adv. Mater. 2015, 27, 1170-1174. [CrossRef]

63. He, Z.; Zhong, C.; Su, S.; Xu, M.; Wu, H.; Cao, Y. Enhanced power-conversion efficiency in polymer solar cells using an inverted device structure. Nat. Photon. 2012, 6, 591-595. [CrossRef]

64. Collins, B.A.; Li, Z.; Tumbleston, J.R.; Gann, E.; McNeill, C.R.; Ade, H. Absolute Measurement of Domain Composition and Nanoscale Size Distribution Explains Performance in PTB7:PC71BM Solar Cells. Adv. Energy Mater. 2013, 3, 65-74. [CrossRef]

65. Reid, D.R.; Jackson, N.E.; Bourque, A.J.; Snyder, C.R.; Jones, R.L.; De Pablo, J.J. Aggregation and Solubility of a Model Conjugated Donor-Acceptor Polymer. J. Phys. Chem. Lett. 2018, 9, 4802-4807. [CrossRef]

66. Liu, Y.; Zhao, J.; Li, Z.; Mu, C.; Ma, W.; Hu, H.; Jiang, K.; Lin, H.; Ade, H.; Yan, H. Aggregation and morphology control enables multiple cases of high-efficiency polymer solar cells. Nat. Commun. 2014, 5, 5293. [CrossRef] [PubMed]

67. Hiemenz, P.C.; Lodge, T.P. Polymer Chemistry, 2nd ed.; CRC Press Taylor \& Francis Group: Boca Raton, FL, USA, 2007.

68. Li, D.; Neumann, A.W. A reformulation of the equation of state for interfacial tensions. J. Colloid Interface Sci. 1990, 137, 304-307. [CrossRef] 
69. Li, D.; Neumann, A.W. Contact angles on hydrophobic solid surfaces and their interpretation. J. Colloid Interface Sci. 1992, 148, 190-200. [CrossRef]

70. Perea, J.D.; Langner, S.; Salvador, M.; Sanchez-Lengeling, B.; Li, N.; Zhang, C.; Jarvas, G.; Kontos, J.; Dallos, A.; Aspuru-Guzik, A.; et al. Introducing a New Potential Figure of Merit for Evaluating Microstructure Stability in Photovoltaic Polymer-Fullerene Blends. J. Phys. Chem. C 2017, 121, 18153-18161. [CrossRef]

71. Belmares, M.; Blanco, M.; Goddard, W.A., III; Ross, R.B.; Caldwell, G.; Chou, S.-H.; Pham, J.; Olofson, P.M.; Thomas, C. Hildebrand and Hansen Solubility Parameters from Molecular Dynamics with Applications to Electronic Nose Polymer Sensors. J. Comput. Chem. 2004, 25, 1814-1826. [CrossRef]

72. Dereje, M.M.; Ji, D.; Kang, S.-H.; Yang, C.; Noh, Y.-Y. Effect of pre-aggregation in conjugated polymer solution on performance of diketopyrrolopyrrole-based organic field-effect transistors. Dyes Pigm. 2017, 145, 270-276. [CrossRef]

73. Yao, K.; Xu, Y.-X.; Wang, X.; Li, F.; Yuan, J. The critical role of additives in binary halogen-free solvent systems for the general processing of highly efficient organic solar cells. RSC Adv. 2015, 5, 93689-93696. [CrossRef]

74. Salim, T.; Wong, L.H.; Bräuer, B.; Kukreja, R.; Foo, Y.L.; Bao, Z.; Lam, Y.M. Solvent additives and their effects on blend morphologies of bulk heterojunctions. J. Mater. Chem. 2011, 21, 242-250. [CrossRef]

75. Lee, J.K.; Ma, W.L.; Brabec, C.J.; Yuen, J.; Moon, J.S.; Kim, J.Y.; Lee, K.; Bazan, G.C.; Heeger, A.J. Processing Additives for Improved Efficiency from Bulk Heterojunction Solar Cells. J. Am. Chem. Soc. 2008, 130, 3619-3623. [CrossRef] [PubMed]

76. Peet, J.; Cho, N.S.; Lee, S.K.; Bazan, G.C. Transition from Solution to the Solid State in Polymer Solar Cells Cast from Mixed Solvents. Macromolecules 2008, 41, 8655-8659. [CrossRef]

77. Liao, H.-H.; Ho, C.-C.; Chang, C.-Y.; Jao, M.-H.; Darling, S.B.; Su, W.-F. Additives for morphology control in high-efficiency organic solar cells. Mater. Today 2013, 16, 326-336. [CrossRef] 